\title{
Strategi Pembangunan Ekonomi Syariah Di Masa Covid-19
}

\author{
Oleh: \\ Dewi Fitrotus Sa'diyah, Mastur \\ Institut Agama Islam Pangeran Diponegoro Nganjuk \\ dewisakhi03@gmail.com
}

\begin{abstract}
Islam anticipates economic development which is considered as part of human development. Its essence is that it enables humans to control the economic environment and improve the quality of life. There are four basic teachings of Islam that deal with the philosophy of Islamic economic development: tawhîd, rubûbiyah, khalîfah and tazkiyah. In this study, using the literature review method, namely using a theory that is relevant to the research problem of Islamic Economic Development Strategies in the Covid-19 Period. The results showed that the principle of tawhid is to prevent concentrated economic power. Khaliffah The principle is to protect against environmental damage and to protect the conservation of natural resources. The principle of tazkiyah to prohibit social inequality and promote equality and justice. In line with that, it can form a continuity of development. The concept of continuity building is basically the application of the rubûbiyah principle, it is the principle of education, maintenance, and continuity of perfection, as a divine (divine) principle. Therefore, if these four principles are realized in Indonesia's development economy, the government will easily create a prosperous and just nation. Then the development strategies offered in the framework of the Islamic economic concept and system are: (1) by distributing direct cash assistance originating from zakat, donations and alms; (2) by strengthening waqf in the form of cash waqf, productive waqf, waqf linked sukuk and waqf for infrastructure; (3) through superior business capital assistance for the business sector or Micro, Small and Medium Enterprises (MSMEs); (4) through the qardhul hasan scheme; (5) increasing Islamic economic and financial literacy; (6) through the development of Islamic financial technology.
\end{abstract}

Keywords: development strategy, Islamic Economics, Covid-19

\section{PENDAHULUAN}

Indonesia di hadapkan dengan banyak persoalan dalam aspek ekonomi akibat dari pandemi Covid19. Kondisi ekonomi di Indonesia nampak memprihatinkan, ekonomi secara global 2020 diperkirakan bisa jatuh seperti depresi 1930, bukan lagi seperti tahun 2008 atau 1998. Kondisi ini juga memicu penurunan perdagangan bahkan perdagangan Internasional. Di Indonesia sendiri berbagai sektor harus terkendala dalam proses operasi, seperti pabrik-pabrik yang harus menghentikan proses operasi karena kondisi tidak memungkinkan. Salah satu dampak yang muncul adalah Pemutusan Hubungan Kerja (PHK) dalam jumlah yang besar, sebagai bagian dari krisis ekonomi. PHK sendiri sudah pasti. Kementerian ketenagakerjaan sendiri melaporkan ada 2,9 Juta karyawan yang di PHK (per Mei 2020), sedangkan KADIN (Kamar Dagang dan Industri Indonesia) justru lebih tinggi, ada 6,4 juta karyawan. Kondisi 
perekonomian di Indonesia dan upaya pemulihannya saat ini yang menjadi fokus dalam upaya penanganan. ${ }^{1}$

Menteri Keuangan Republik Indonesia, Sri Mulyani Indrawati, memprediksi pertumbuhan ekonomi dalam skenario terburuk mencapai minus $0,4 \% .^{2}$ Menurut Bank Dunia, dampak ekonomi dari Covid-19 ini akan menghentikan usaha hampir 24 juta orang di Asia Timur dan Pasifik. Bank Dunia juga memperkirakan hampir 35 juta orang akan tetap dalam kemiskinan. Bahkan melalui sejumlah skenario dengan mempertimbangkan berbagai garis kemiskinan, Bank Dunia memperkirakan jumlah orang yang hidup dalam kemiskinan ekstrim akan meningkat hingga 922 juta di seluruh dunia. Sebuah angka yang fantastis. Di antara bentuk upaya yang diserukan dan dilakukan oleh dunia dalam rangka mengurangi penyebaran wabah ini adalah dengan social atau physical distancing. Namun sayangnya, gerakan ini membawa pengaruh pada penurunan aktivitas ekonomi secara keseluruhan. ${ }^{3}$

Dengan kondisi seperti ini, timbul pertanyaan besar: bagaimana Indonesia mampu melaluinya? Apa yang dimiliki bangsa ini agar mampu bertahan di tengah gelombang wabah yang belum pasti kapan akan berakhir? Sebagai negara dengan populasi muslim terbesar di dunia, umat Islam dapat memberikan peran terbaiknya melalui berbagai bentuk atau model filantropi dalam Ekonomi Syariah. Peran ini diharapkan dapat mengatasi guncangan ekonomi yang terjadi dan seluruh masyarakat, khususnya umat muslim, dapat ikut serta berkontribusi dalam memulihkan guncangan tersebut. ${ }^{4}$

\section{METODE PENELITIAN}

Metode yang digunakan dalam penelitian ini adalah kajian pustaka. Adapun metode penelitian kajian pustaka atau studi kepustakaan yaitu berisi teori teori yang relevan dengan masalah masalah penelitian. Adapun masalah pada penelitian ini adalah untuk mengetahui Strategi Pembangunan Ekonomi Syariah di masa covid-19. Pada bagian ini dilakukan pengkajian mengenai konsep dan teori yang digunakan berdasarkan literatur yang tersedia, terutama dari artikel-artikel yang dipublikasikan dalam berbagai jurnal ilmiah. Kajian pustaka berfungsi untuk membangun konsep atau teori yang menjadi dasar studi dalam penelitian. ${ }^{5}$ Kajian pustaka atau studi pustaka merupakan kegiatan yang diwajibkan dalam penelitian, khususnya penelitian akademik yang tujuan utamanya adalah mengembangkan aspek teoritis maupun aspek manfaat praktis. ${ }^{6}$

Dilihat dari jenis penelitiannya, yang digunakan dalam penelitian ini adalah penelitian kepustakaan atau library research, yakni penelitian yang dilakukan melalui mengumpulkan data atau karya tulis ilmiah yang bertujuan dengan obyek penelitian atau pengumpulan data yang bersifat kepustakaan, atau telaah

${ }^{1}$ https://www.uii.ac.id/ekonomi-di-masa-pandemi-covid-19/. Diakses pada tanggal 14 Agustus 2020

2 Azwar. Solusi Ekonomi dan Keuangan Islam di Masa Pandemi Covid-19. https://www.kemenkeu.go.id/publikasi/artikel-dan-opini/solusi-ekonomi-dan-keuangan-islam-sa at-pandemi-covid$19 /$

3 World Bank, "World Bank Group and COVID-19 (coronavirus)". https://www.worldbank.org/en/who-weare/news/coronavirus-covid19. Diakses pada tanggal 14 Agustus 2020.

4 Azwar. Solusi Ekonomi dan Keuangan Islam di Masa Pandemi Covid-19. https://www.kemenkeu.go.id/publikasi/artikel-dan-opini/solusi-ekonomi-dan-keuangan-islam-saat-pandemi-covid19/. Diakses pada tanggal 14 Agustus 2020.

${ }^{5}$ V.Wiratna Sujarweni, Metodeologi Penelitian (Yogyakarta: Pustaka Baru Perss, 2014), hlm.57

${ }^{6}$ Sukardi, Metodologi Penelitian Pendidikan Kompetensi dan Praktiknya (Jakarata: PT Bumi Aksara,2013), h.33 
yang dilaksanakan untuk memecahkan suatu masalah yang pada dasarnya tertumpu pada penelaahan kritis dan mendalam terhadap bahan-bahan pustaka yang relevan. Dilihat dari sifatnya, maka penelitian ini termasuk penelitian deskriptif, penelitian deskriptif berfokus pada penjelasan sistematis tentang fakta yang diperoleh saat penelitian dilakukan. ${ }^{7}$

Metode pengumpuluan data penelitian ini diambil dari sumber data, Yang dimaksud sumber data dalam penelitian adalah subjek dari mana data dapat diperoleh. Apabila peneliti menggunakan dokumentasi, maka dokumen atau catatanlah yang menjadi sumber data, sedangkan isi catatan subjek penelitian atau variable penelitian. ${ }^{8}$ Data-data tersebut diperoleh dari dua sumber, yaitu: (a) Data primer yang dimaksud adalah jurnal-jurnal tentang strategi manajemen, strategi pembangunan, keuangan negara, ketenaga kerjaan, ekonomi syariah, dan artikel-artikel tentang covid-19, serta bacaan terpercaya yang dapat mendukung penelitian ini. (b) Data skunder adalah sumber-sumber yang diambil dari sumber yang lain yang tidak diperoleh dari sumber primer. Sumber-sumber yang dimaksud adalah buku-buku lain yang berhubungan dengan permasalahan yang menjadi pokok bahasan penelitian ini.

Setelah keseluruhan data terkumpul maka langkah selanjutnya penulis menganalisa data tersebut sehingga ditarik suatu kesimpulan. Untuk memperoleh hasil yang benar dan tepat dalam menganalisa data, penulis menggunakan teknik analisis isi. Analisis isi (Content Analysis) adalah penelitian yang bersifat pembahasan mendalam terhadap isi suatu informasi tertulis atau tercetak di media massa. Analisis isi dapat digunakan untuk menganalisa semua bentuk komunikasi, baik surat kabar, berita radio, iklan televisi maupun semua bahan dokumentasi yang lainnya. ${ }^{9}$ Sedangkan kaitannya dengan pembahasan yaitu sebagai salah satu upaya penulis dalam memudahkan pemahaman dengan cara menganalisa kebenarannya melalui pendapat para ulama yang kemudian diambil makna dan intisari dari pendapat para ulama tersebut, yang berkenaan dengan strategi pembangunan ekonomi syariah.

Adapun langkah-langkah strategis dalam penelitian analisis isi, sebagai berikut: Pertama, Penetapan desain atau model penelitian. Disini ditetapkan beberapa media, analisis perbandingan atau korelasi, objeknya banyak atau sedikit dan sebagainnya. Kedua, pencarian data pokok atau data primer, yaitu teks sendiri. Sebagai analisis isi, teks merupakan objek yang pokok, bahkan terpokok. Pencarian dapat dilakukan dengan menggunakan lembar formulir pengamatan tertentu yang sengaja dibuat untuk keperluan pencarian data tersebut. Ketiga, pencarian pengetahuan konstektual agar penelitian yang dilakukan tidak berada diruang hampa, tetapi terlihat kait-mengait dengan faktor- faktor lain. ${ }^{10}$

\section{HASIL DAN PEMBAHASAN}

\subsection{Hasil Penelitian}

Sistem ekonomi Islâm berangkat dari kesadaran tentang etika, sebuah ethical ekonomi, sedangkan sistem ekonomi lain, baik kapitalisme maupun sosialisme, berangkat dari kepentingan (interest). Kapitalisme berangkat dari kepentingan perorangan (selfishness) dan sosialisme berangkat dari kepentingan kolektif (collectivisme). Dengan ekonomi bedasar etika itu agama tidak

\footnotetext{
${ }^{7}$ Anwar Sanusi, Metodologi Penelitian Bisnis, (Jakarta: Salemba Empat,2016), h.32

${ }^{8}$ Suharsimi Arikuntoro, Prosedur Penelitian Suatu Pendekatan Praktik, (Jakarta: Rieneka Cipta, 2006), hlm. 26

${ }^{9}$ Afifudin, Et.al, Metodologi Penelitian Kualitatif, (Pustaka Setia: Bandung,2012), hlm.165

${ }^{10}$ Afifudin, Et.al, Metodologi Penelitian Kualitatif, (Pustaka Setia: Bandung,2012), hlm. 168
} 
menjadi alat bagi suatu kepentingan. Tugas umat ialah memikirkan bahwa agamanya menghendaki sebuah ethical economy tetapi tetap tanggap kepada kepentingan-kepentingan yang nyata. ${ }^{11}$

Mengenai etika Islâm dalam ekonomi, Syed Nawab Haider Nagwi, menyebutkan empat aksioma etika, yaitu tawhîd, keseimbangan, kehendak bebas, dan pertanggung jawaban. ${ }^{12}$ Keempat aksioma itu penulis uraikan sebagai berikut; pertama, etika tawhîd mempunyai dua tujuan: (1) mengukuhkan bahwa manusia adalah makhluk teomorfik; 2) mengukuhkan fungsi integrative dari tawhîd. Manusia adalah makhluk teomorfik berarti bahwa manusia adalah makhluk Ilâhiyah, maksudnya manusia adalah makhluk, tetapi akhlaknya harus meniru akhlak Tuhan. Tawhîd juga berarti integrasi manusia, manusia itu merupakan sebuah kesatuan, satu dengan lainnya tak terpisahkan. Ini berarti bahwa kolektifitas itu diakui adanya oleh Islâm. Kedua, etika keseimbangan adalah dimensi horisontal antar-manusia, sebagai tambahan al-'adl (berbuat adil) yang merupakan dimensi vertikal (karena adil hanya mungkin dikerjakan oleh yang kuat terhadap yang lemah). Keseimbangan berarti tidak berlebih-lebihan dalam mengejar kepentingan ekonomi. Dalam surat al-A'râf (7): 31 disebutkan:

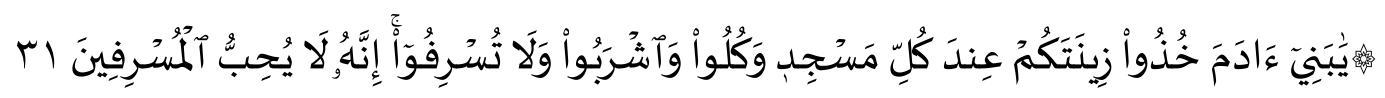

Inti makna dari ayat diatas adalah aturan Islam yakni "Makan dan minumlah, dan jangan berlebih-lebihan. Selfishness yang tak terbatas dilarang oleh Islâm, untuk itu masyarakatlah yang menentukan kriteria berlebih-lebihan itu. Ketiga, etika kehendak bebas. Manusia sebagai individu dan kolektivitas mempunyai kebebasan penuh untuk menentukan nasibnya sendiri.

Dalam ekonomi berarti ada kebebasan penuh untuk mengaplikasikan kaidah-kaidah Islâm. Karena kegiatan ekonomi bukanlah ibadah, tapi muâmalah, maka kaidahnya adalah semua boleh, kecuali yang dilarang. Yang dilarang dalam Islâm adalah ketidakadilan dan ribâ. ${ }^{13}$ Mengenai ketidakadilan akan jelas dengan sendirinya setelah mengikuti uraian di bawah nanti. Sementara tentang ribâ buku yang paling komprehensif ialah M. Umer Chapra, Towards a Just Monetary System, (London: The Islamic Foundation, 1985). Keempat, pertanggungjawaban. Terdiri dari dua, yaitu amanah (melaksanakan tangung jawab) dan accountability (diperhitungkan). Dalam surat alMa’ârij (70): 32

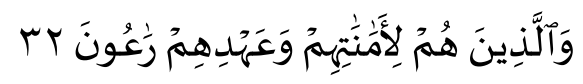

\section{"Dan orang-orang yang memelihara amanat amanat (yang dipikulnya) dan janjinya".}

Selanjutnya dikatakan (ayat 35) bahwa mereka itu kekal di surga lagi dimuliakan. Kekayaan adalah amanah Tuhan, yang harus dipertangungjawabkan penggunaannya. Mengenai accountability, dalam surat al-Nisâ' (4): 86 disebutkan:

\footnotetext{
${ }^{11}$ Kuntowijoyo, Identitas Politik Umat Islam (Bandung: Mizan, 1997), hlm. 135-136

12 Syed Nawab Haider Nagwi, Etika dan Ilmu Ekonomi: Suatu Sintesis Islami (Bandung: Mizan, 1985), hlm. 123-125

${ }^{13}$ Riba bukan cuma berarti bunga atas pinjaman. Ia memiliki arti ketidaksetaraan dalam pertukaran, baik perbedaan tersebut timbul dari pertukaran jumlah yang tidak sama ataupun dari adanya risiko yang tidak ikut dipikul oleh pihak lain dalam kontrak.
} 


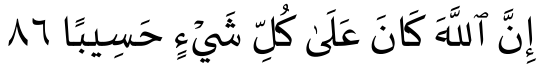

"Sesunguhnya Allâh memperhitungkan segala sesuatu”.

Jadi segala aktifitas manusia di dunia ini, apapun bentuk dan motivasinya, maka harus dilaksanakan dengan rasa tanggungjawab karena akan diperhitungkan di hadapan Allâh SWT.

Konsep Pembangunan Islâmi Pada bagian ini, penulis akan mengulas beberapa unsur konsep pembangunan yang Islâmi. Pembangunan ekonomi, menurut beberapa literatur pembangunan belakangan ini, adalah meningkatnya produktivitas ekonomi secara keseluruhan maupun para pekerja dan juga meningkatnya perbandingan antara pendapatan dengan jumlah total penduduk. Hal ini merupakan proses yang dinamis dan struktural yang akan menghasilkan perbaikan tampilan ekonomi secara berkelanjutan, aktual dan potensial. Biasanya dihitung dalam istilah per kapita dan membentang dalam kurun waktu tertentu.

Substansinya terletak pada dimungkinkannya manusia untuk mengendalikan lingkungan ekonominya sekaligus untuk memperbaiki kualitas hidup mereka. Islâm sangat memperhatikan masalah pembangunan ekonomi, namun tetap menempatkannya sebagai bagian dari persoalan yang lebih besar, yaitu pembangunan umat manusia. Fungsi utama Islâm adalah membimbing manusia pada jalur yang benar dan arah yang tepat. Semua aspek yang berkaitan dengan pembangunan ekonomi harus menyatu dengan pembangunan umat manusia secara keseluruhan. Khurshid Ahmad, merumuskan empat prinsip yang dapat diturunkan dari ajaran Islâm sebagai dasar-dasar filosofis pembangunan yang Islâmi, ${ }^{14}$ dapat sijelaskan sebagai berikut:

a. Tawhîd, yang meletakkan dasar-dasar hubungan antara Allâh manusia dan manusia dengan sesamanya.

b. Rubûbiyah, yang menyatakan dasar-dasar hukum Allâh untuk selanjutnya mengatur model pembangunan yang bernafaskan Islâm.

c. Khalîfah, yang menjelaskan status dan peran manusia sebagai wakil Allâh di muka bumi. Pertanggung jawaban ini menyangkut manusia sebagai Muslim maupun sebagai anggota dari umat manusia. Dari konsep ini lahir pengertian tentang perwalian moral, politik, ekonomi, serta prinsip-prinsip organisasi soial lainnya.

d. Tazkiyah, misi utama utusan Allâh adalah menyucikan manusia dalam hubungannya dengan Allâh, sesamanya, alam lingkungan, masyarakat dan negara.

Selanjutnya, Khurshid Ahmad menegaskan bahwa konsep pembangunan yang Islâmi sebenarnya dapat ditarik dari konsep tazkiyah, yang berarti penyucian terhadap sikap dan hubungan tersebut di muka bumi. Hasil dari tazkiyah adalah falâh, yaitu sukses di dunia maupun di akhirat. ${ }^{15}$ Keempat asas tersebut secara substansial telah terimplemetasi di dalam Pancasila yang merupakan dasar dan ideologi negara Indonesia. Namun, sekilas kita bisa bertanya, mengapa hanya empat saja,

14 Khurshid Ahmed, "Economic Development in an Islamic Fremwork" dalam Studies Islamic Economics (Jeddah: King Abdul Aziz University, 1976), hlm. 178-179

15 Ibid. 
dan mengapa konsep-konsep itu yang dipilih? Bagaimana halnya dengan prinsip al-adl (keadilan), misalnya? Padahal salah satu prinsip Islâm di bidang ekonomi adalah keadilan (al-adl). Aspek keadilan ini sebenarnya terdapat dalam asas tazkiyah. Maka, bagi kita sebenarnya bisa memilih teori yang dianggap sejalan dengan yang sedang kita pikirkan di Indonesia, yang kita sebut dengan Ekonomi Pancasila.

Asas tawhîd, khalîfah dan tazkiyah pada akhirnya menuju ke perwujudan pembangunan yang berkelanjutan. Asas tawhîd mencegah konsentrasi kekuatan ekonomi. Asas khalîfah mencegah kerusakan lingkungan dan perlindungan terhadap kelestarian sumber daya. Dan asas tazkiyah mencegah kepincangan sosial dan mewujudkan pemerataan yang bermuara pada keadilan. Kesemuanya itu akan mewujudkan pembangunan yang berkelanjutan. Konsep pembangunan berkelanjutan pada hakikatnya adalah pelaksanaan asas rubûbiyah, yakni asas pendidikan, pemeliharaan dan kontinuitas menuju kepada kesempurnaan, seperti sifat Ilâhî.

Dengan demikian, jika keempat nilai yang dirumuskan oleh Khursyid Ahmad tersebut dapat terealisasikan dalam pembangunan ekonomi yang dibangun di Indonesia, maka negara akan dengan mudah mewujudkan cita-cita bangsa, yaitu negara yang sejahtera dan berkeadilan. Langkah Kebijakan Pembangunan Ekonomi yang berbasis Islâm Dari empat elemen-elemen strategis yang telah diuraikan di atas, selanjutnya perlu adanya kebijakan-kebijakan dari sebuah negara untuk merealisasikan pembangunan ekonomi yang berorientasi pada kesejahteraan yang berkeadilan. Oleh karena itu, Umer Chapra menawarkan lima kebijakan, yaitu: ${ }^{16}$

a. Menghidupkan Faktor Kemanusiaan

Untuk merealisasikan maqâshid dalam lingkungan politik yang kondusif perlu adanya motivasi faktor kemanusiaan untuk mencapai tingkat alokasi yang efektif dan efisien serta distribusi sumber daya yang merata, manusia harus senantiasa didorong untuk bersedia melakukan yang terbaik dan memanfaatkan sumber-sumber daya yang langka dengan tingkat efisiensi yang tinggi. Untuk memotivasi ke arah tesebut diperlukan injeksi moral ke dalam nafsu pemenuhan kepentingan diri sendiri agar kepentingan sosial tetap terjaga, walaupun harus mengesampingkan kepentingan diri sendiri.

b. Mengurangi Konsentrasi Kekayaan

Hambatan yang paling serius bagi pembangunan yang berkeadilan adalah konsentrasi kepemilikan atau kekayaan. Konsentrasi kekayaan dan pendapatan harus dihilangkan untuk mencapai pemerataan yang berkeadilan, sebagaimana firman Allâh:

${ }^{16}$ Di antara kebijakan-kebijakan strategis ini penekanannya adalah dimensi moral yang dimasukkan ke dalam barometer pembangunan material. Karena, menurut Umer Chapra, pembangunan tanpa sebuah integrasi moral dan material akan sulit mewujudkan efisiensi dan pemerataan. Lihat, M. Umer Chapra, Islam and Economic Development (Islamabad: The International Institute of Islamic Thought, 1993), hlm. 70-71 


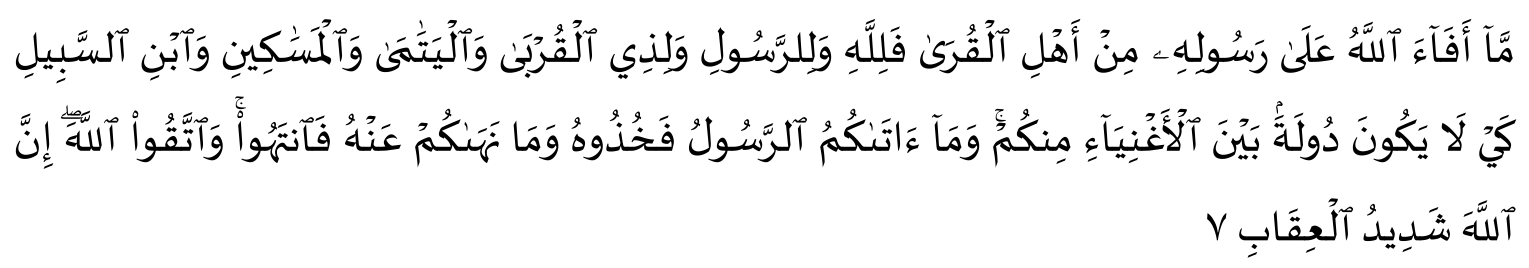

"Apa-apa (harta rampasan) yang diberikan Allâh pada Rasul-Nya berasal dari penduduk kotakota adalah untuk Allâh dan untuk Rasul, kerabat Rasul, anak-anak yatim, orang-orang miskin dan orang-orang yang dalam perjalanan, supaya harta itu jangan hanya beredar di antara orang-orang kaya saja di antara kamu (QS. Al-Hasyr/59: 7). ${ }^{17}$

a. Melakukan Restrukturisasi Ekonomi

Realokasi sumber-sumber daya yang diperlukan untuk pembangunan yang merata tidak akan berjalan tanpa adanya suatu penataan kembali semua aspek ekonomi, yang meliputi konsumsi swasta, keuangan pemerintah, formasi kapital dan produksi.18 Konsumsi merupakan salah satu kegiatan ekonomi yang cukup vital, karena konsumsi merupakan salah satu kegiatan utama dalam perekonomian, oleh karena itu kesalahan pandangan dalam konsumsi akan berakibat fatal terhadap kondisi makro ekonomi.

Dengan demikian, perlu adanya penyaringan pola konsumsi, yang tentunya sesuai dengan nilai-nilai Islâm. ${ }^{19}$ Untuk menciptakan pemerataan dan efisiensi harus ada pembedaan antara yang penting dan yang tidak penting, antara kebutuhan, kemewahan, dan perantara (intermediat). Dalam nilai-nilai Islâm yang diutamakan adalah kepentingan guna pemenuhan kebutuhan. Sedangkan lainnya adalah turunannya. Turunan tersebut diperbolehkan selama tidak bertentangan dengan syari at dan berorirentasi pada keadilan sosio ekonomi.

b. Melakukan Restrukturisasi Keuangan

Tujuan untuk mencapai pengembangan pedesaan dan perkotaan dalam memecahkan problema utama perekonomian, seperti pengangguran dan konsentrasi kekayaan akan menjadi mimpi yang indah kecuali ada persiapan-persiapan pengembangan dan pembiayaannya. Invetasi dan tabungan yang dikelola oleh lembaga-lembaga keuangan harus memberikan prioritas pada pengembangan tersebut. Deposito-deposito atau tabungan harus diarahkan pembiayaannya pada sektor-sektor riil perekonomian. Deposito itu berasal dari masyarakat, maka adalah rasional jika ia disalurkan untuk kesejahteraan masyarakat, bukan

${ }^{17}$ Rifai, Tafsîr al-Qurân, hlm. 980

${ }^{18}$ Chapra, Islam dan Tantangan, hlm. 279

${ }^{19}$ Keadilan sosial juga mengurangi konsumsi yang berlebihan dan investasi terkait yang dipromosikan oleh kesenjangan pendapatan di kalangan orang kaya. Hal ini melepaskan sumber-sumber daya untuk memenuhi kebutuhan orang miskin, dengan cara meningkatkan pendidikan, jaminan kesehatan, dan tenaga kerja yang sejahtera untuk mendorong pertumbuhan ekonomi yang lebih cepat dan berkesinambungan. Selain itu, pengurangan penderitaan rakyat miskin dengan menghilangkan perasaan antisosial di antara mereka, meningkatkan motivasi kerja mereka, dan efisiensi serta mengurangi pemborosan sebagai akibat dari pemogokan dan konflik. Lihat, Ibid., hlm. 197-198 
untuk kesejahteraan segelintir orang.20 Untuk mengarahkan sistem finansial, harus ada nilainilai yang mendasarinya yang mempunyai orientasi kesejahteraan seluruh umat manusia. Islâm, dalam hal ini telah menyediakan sistem yang dimaksud. Oleh karena itu perombakan sistem finansial sesuai dengan nilail-nilai Islâm mutlak diperlukan.

c. Perencanaan Kebijakan Strategis

Perencanaan ini harus menetapkan perubahan struktur yang diperlukan dalam ekonomi untuk memenuhi kebutuhan, mengurangi pengangguran dan meningkatkan pertumbuhan ekonomi tanpa menciptakan ketidak seimbangan antara mikro ekonomi dan makro ekonomi. Rencana ini juga harus menunjukkan institusi-institusi yang perlu didirikan atau direformasi untuk mengurangi adanya kesenjangan pendapatan dan kekayaan yang ada, serta mewujudkan suatu pemilikan perusahaan dan aset perolehan pendapatan yang mempunyai sumber yang besar. Selain itu, perlu dilakukan reformasi sistem perbankan sesuai dengan ajaran Islâm, yang akan menuntut perhatian khusus perencanaan, karena besarnya sumbangan yang diberikannya untuk menjadikan alokasi sumber daya secara efisien dan adil. Juga tidak kalah pentingnya adalah reformasi secara sungguh-sungguh dalam sistem pendidikan untuk melahirkan tenaga-tenaga yang terampil dan produktif. Ringkasnya, rencana ini tidak boleh hanya memusatkan kepada satu langkah saja atau bersandar kepada kontrol yang tidak semestinya, tetapi ia harus menggunakan seluruh kebijakan dan berkesinambungan untuk merealisasikan tujuan-tujuan yang hendak dicapai. Hal ini harus merefleksikan suatu perubahan yang jelas dan dapat dimengerti dalam filsafat dan strategi pembangunan. Semua kebijakan fiskal, moneter, pendapatan, impor dan produksi harus dirumuskan dalam kerangka rencana kebijakan strategis ini. ${ }^{21}$

\subsection{Pembahasan Penelitian}

\section{Strategi Pembangunan Ekonomi Syariah di masa Covid-19}

Di antara strategi ekonomi syariah yang dapat ditawarkan dalam kerangka konsep dan sistem Ekonomi Islam adalah penyaluran bantuan langsung tunai yang berasal dari zakat, infak dan sedekah, baik yang berasal dari unit-unit pengumpul zakat maupun dari masyarakat. Menghadapi situasi seperti saat ini, bukan hanya pemerintah yang bergerak, masyarakat pun diharapkan dapat berkontribusi sesuai dengan kemampuan dan kondisinya masing-masing.

Dalam konteks ini, diperlukan pengorbanan dari orang kaya dan kesabaran dari orang miskin yang terdampak wabah, atas dasar cinta yang diwujudkan dalam bentuk solidaritas sesama manusia, di mana orang yang lebih beruntung membantu mereka yang kurang beruntung.22 Salah satu bentuk nya, di tengah pandemi Covid-19, adalah dengan menunaikan zakat, infak, dan sedekah. Khusus untuk zakat yang ditunaikan, penyalurannya dapat difokuskan kepada orang miskin yang terdampak Covid-19 secara langsung, sebagai salah satu yang berhak menerimanya (mustahik).

${ }^{20}$ Chapra, Islam and Economic, hlm. 109

${ }^{21}$ Ibid., hlm. 100

${ }^{22}$ Linge, A., Filantropi Islam Sebagai Instrumen Keadilan Ekonomi (Jurnal Perspektif Ekonomi Darussalam, Vol . 1, No. 2, 2015), hlm. 154-171. 
Penguatan kampanye dana zakat, infak, dan sedekah dapat terus digiatkan. Diantara upaya yang dapat dilakukan adalah:

a. Menjadikan masjid sebagai pusat baitul maal untuk masyarakat sekitarnya dan wajib didaftar sebagai Unit Pengumpul Zakat (UPZ) di bawah koordinasi Organisasi Pengelola Zakat (OPZ).

b. Literasi terkait perhitungan zakat dapat dikuatkan dengan pendirian Zakat Centre di masjid dan kampus-kampus.

c. Perlu menyerukan gerakan Solidarity Fund secara nasional dan besar-besaran yang dapat dipimpin langsung oleh Presiden Republik Indonesia yang didukung oleh seluruh media mainstream nasional atau media sosial resmi pemerintah dan masyarakat.

Penguatan wakaf uang baik dengan skema wakaf tunai, wakaf produktif maupun waqf linked sukuk perlu ditingkatkan. Badan Wakaf Indonesia (BWI) perlu bekerja sama dengan lembaga keuangan syariah untuk mempromosikan skema wakaf ini, yang pada akhirnya dapat digunakan untuk pembangunan berbagai infrastruktur berbasis wakaf seperti Rumah Sakit Wakaf (RSW) khusus korban Covid-19, Alat Pelindung Diri (APD) wakaf, masker wakaf, poliklinik wakaf, Rumah Isolasi Wakaf (RIW), pengadaan ventilator wakaf, universitas wakaf dan lainnya. Manajemen wakaf harus dilakukan secara profesional, sehingga wakaf dapat dimanfaatkan secara produktif dan berkelanjutan, mengingat realita bahwa banyak harta benda wakaf yang ada, tetapi kurang dan bahkan tidak diproduktifkan, sehingga tidak bermanfaat secara maksimal. ${ }^{23}$ Bahkan, dengan perkembangan saat ini, wakaf dapat saja berbentuk benda apa saja yang bernilai ekonomi, antara lain paten sebagai wakaf produktif.

Pada saat nanti vaksin untuk Covid-19 ditemukan, diharapkan patennya dapat diwakafkan, sehingga dapat digunakan untuk seluruh masyarakat dunia. Oleh karena itu, penting untuk mengampanyekan pentingnya wakaf saat wabah pandemi Covid-19 kepada masyarakat termasuk kepada ilmuwan dan penemu (peneliti vaksin).

Bantuan modal usaha unggulan saat krisis. Di tengah-tengah krisis, tidak sedikit sektor usaha atau Usaha Mikro Kecil Menengah (UMKM) yang berjuang agar tetap eksis. Usaha ini seringkali sulit bertahan karena keterbatasan permodalan. Keberadaan UMKM sebagai kelompok nonmuzakki adalah kelompok yang sangat rentan untuk jatuh ke dalam jurang kemiskinan dan kebangkrutan karena guncangan atau hantaman shock ekonomi. Sehingga jumlah mustahik dapat meningkat dengan sangat tajam, sementara jumlah muzakki dapat terus menurun secara signifikan. ${ }^{24}$

${ }^{23}$ Sakni, A. S., Konsep Ekonomi Islam dalam Mengentaskan Kesenjangan Sosial: Studi atas Wacana Filantropi Islam dalam Syari'at Wakaf (Jurnal Ilmu Agama: Mengkaji Doktrin, Pemikiran, Dan Fenomena Agama, Vol. 14, No. 1, 2013), hlm. 151-166

${ }^{24}$ Sabirin, S., \& Sukimin, D. A., Islamic Micro Finance Melati: Sebuah Upaya Penguatan Permodalan bagi Pedagang Pasar Tradisional (Economica: Jurnal Ekonomi Islam, Vo. 8, No. 1, 2017), hlm. 27-53. 
Permodalan usaha di atas juga dapat diikuti dengan dengan pinjaman qardhul hasan. Dalam terminologi ekonomi/keuangan syariah, qardhul hasan adalah pinjaman yang tidak mengambil manfaat (keuntungan) apa pun namun tetap ditekankan untuk dibayarkan kembali. ${ }^{25}$

\section{KESIMPULAN}

Dari uraian di atas, penulis dapat menarik suatu kesimpulan bahwa Ekonomi Islâm pada hakikatnya adalah suatu upaya untuk memformulasikan suatu ilmu ekonomi yang berorientasi kepada manusia dan masyarakat yang tidak mengakui individualisme yang berlebihan, juga tidak membenarkan kolektifitas yang melanggar hak-hak perorangan, dengan berdasarkan kepada nilainilai Islâm, yaitu al-Qur'ân dan as-Sunnah. Tujuan ekonomi Islâm seirama dengan tujuan pokok Islâm, yaitu menciptakan kesejahteraan bagi semua umat manusia. Kesejahteraan ini meliputi kepuasan fisik dan kedamaian mental yaitu kebahagiaan, yang hal ini dapat diperoleh melalui realisasi yang seimbang antara kebutuhan materi dan rohani dari personalitas individu. Pemenuhan kebutuhan rohani membutuhkan pembangunan moral, dan pemenuhan kebutuhan materi dapat direalisasikan dengan pembangunan umat manusia dan sumber daya yang ada dalam suatu pola yang menyatu sehingga semua kebutuhan manusia, dapat dipenuhi secara utuh dan terwujud suatu distribusi kekayaan yang adil dan merata. Sebagai negara dengan populasi muslim terbesar di dunia, umat Islam dapat memberikan peran terbaiknya melalui berbagai bentuk atau model philanthropy dalam Ekonomi Syariah, khususnya dalam masa pandemi Covid-19.

Peran ini diharapkan dapat mengatasi guncangan ekonomi yang terjadi dan seluruh masyarakat, khususnya umat muslim, dapat ikut serta berkontribusi dalam memulihkan guncangan tersebut. Di antara solusi yang dapat ditawarkan dalam kerangka konsep dan sistem Ekonomi dan Keuangan Sosial Islam adalah: (1) dengan penyaluran bantuan langsung tunai yang berasal dari zakat, infak dan sedekah; (2) dengan penguatan wakaf baik berupa wakaf uang, wakaf produktif, waqf linked sukuk maupun wakaf untuk infrastruktur; (3) melalui bantuan modal usaha unggulan untuk sector usaha atau Usaha Mikro Kecil Menengah (UMKM); (4) melalui skema qardhul hasan; (5) peningkatan literasi ekonomi dan keuangan syariah; (6) melalui pengembangan teknologi finansial syariah. Jika program-program di atas, khususnya bantuan langsung tunai, zakat, infak, wakaf, atau CSR, betul-betul dapat digalakkan, maka diharapkan akan membantu surplus ekonomi terbentuk kembali sehingga percepatan pemulihan ekonomi dapat terwujud.

\section{UCAPAN TERIMA KASIH}

Untuk dapat menyelesaikan penelitian ini, penulis mendapatkan berbagai bantuan dari beberapa pihak. Oleh karena itu penulis berkewajiban menyampaikan rasa terima kasih sedalamdalamnya, terutama kepada: Rektor Institut Agama Islam Pangeran Diponegoro (IAI PD) Nganjuk yang telah memberikan izin kepada penulis untuk dapat menyelesaikan studi akhir. Dekan Fakultas Syariah dan Ekonomi Islam, yang telah memberikan izin dan pengarahan pada penulis akhir studi ini. Dan para pembimbing yang telah memberikan bimbingan dengan penuh kesabaran sehingga dapat terselesaikannya penulisan ini.

${ }^{25}$ Sari, S. P., Pengaruh Pembiayaan Qardhul Hasan Terhadap Peningkatan Pendapatan Usaha Mustahik Zakat (Studi Kasus Dompet Peduli Umat Daarut Tauhiid Cabang Bogor) (AL-INFAQ, Vol. 4, No. 1, 2015), hlm.57-93 


\section{REFERENSI}

Ahmed, Khurshid, ed. Islamic Perspectives. Leicester: Islamic Foundation, 1979

Ahmed, Khurshid, ed. Economic Development in an Islamic Fremwork dalam Studies Islamic Economics. Jeddah: King Abdul Aziz University, 1976

Ascarya. (2020). The Role of Islamic Social Finance in Times of Covid-19 Outbreak. PEBS-UI.

Asri, A., Aqbar, K., \& Iskandar, A. (2020). Hukum dan Urgensi Wakaf Tunai dalam Tinjauan Fikih. Bustanul Fuqaha: Jurnal Bidang Hukum Islam, 1(1)

Azwar. Solusi Ekonomi dan Keuangan Islam di Masa Pandemi Covid-19. https://www.kemenkeu.go.id/publikasi/artikel-dan-opini/solusi-ekonomi-dan-keuangan-islamsaat-pandemi-covid-19/. Diakses pada tanggal 14 Agustus 2020.

Baihaqi, Abu Bakar Ahmad bin al-Husien bin Ali al. as-Sunan al-Kubrâ li al-Baihaqi, Juz 2,

Buraey, Muhammad A Al-. Islam landasan Alternatif Administrasi Pembangunan. Jakarta: CV. Rajawali, 1986

Chapra. M. Umer. Islam and Economic Development. Islamabad: The International Institute of Islamic Thought, 1993

Chapra. M. Umer. The Future of Economic: An Islamic Perspective, terj. Amdiar Amir, et.al. Jakarta: Syariah Economic and Banking Institute, 2001

Chapra. M. Umer. Islam dan Tantangan Ekonomi, terj. Ikhwan Abidin Basri. Jakarta: Tazkia Institut dan GIP, 2000

Chapra. M. Umer. Sistem Moneter Islam, terj. Ikhwan Abidin Basri. Jakarta: Tazkia Institut, 2000

Baldwin, R., Mauro, B.W.D. (2020). Economics in the Time of Covid-19. NEW E-BOOK. The Graduate Institute Geneva. p. 1-10.

Hiedar Abad: Dâirah al-Ma’ârif. 1344 H.. dalam al-Maktabah al-Syâmilah.

Haider Nagwi, Syed Nawab. Etika dan Ilmu Ekonomi: Suatu Sintesis Islami. Bandung: Mizan, 1985

Hayati, S. R. (2019). Strategi Bank Syariah dalam Meningkatkan Literasi Keuangan Syariah pada Masyarakat (Studi Kasus pada BPRS Madina Mandiri Sejahtera). JESI (Jurnal Ekonomi Syariah Indonesia), 8(2)

Hiyanti, H., Nugroho, L., Sukmadilaga, C., \& Fitrijanti, T. (2020). Peluang dan Tantangan Fintech (Financial Technology) Syariah di Indonesia. Jurnal Ilmiah Ekonomi Islam, 5(3)

Institut Tazkia. (2020). Tujuh Paket Ekonomi dan Keuangan Syariah Mengatasi Dampak Krisis Covid-19. Bogor: Institut Tazkia. 
Iskandar, A., Aqbar, K. (2019). Kedudukan Ilmu Ekonomi Islam di Antara Ilmu Ekonomi dan Fikih Muamalah: Analisis Problematika Epistemologis. Nukhbatul 'Ulum: Jurnal Bidang Kajian Islam, Vol. 5, No. 2 (2019)

Kasdi, A. (2016). Filantropi Islam Untuk Pemberdayaan Ekonomi Umat (Model Pemberdayaan ZISWAF di BMT Se-Kabupaten Demak). Iqtishadia: Jurnal Kajian Ekonomi dan Bisnis Islam STAIN Kudus, 9(2)

Kuntowijoyo. Identitas Politik Umat Islam. Bandung: Mizan, 1997

Linge, A. (2015). Filantropi Islam Sebagai Instrumen Keadilan Ekonomi. Jurnal Perspektif Ekonomi Darussalam, 1(2)

Lubis, N. I. (2019). Peran Masyarakat Ekonomi Syariah (MES) Dalam Meningkatkan Literasi Keuangan Syariah Di Indonesia (Doctoral dissertation, Universitas Islam Negeri Sumatera Utara).

Mubarok, F. K. (2019). Optimalisasi Produk Qardhul Hasan Dalam Memberdayakan Ekonomi Umat. Akuntabel, 16(1)

Mutahhari, Murtadha. Masyarakat dan Sejara; Kritik Islam atas Marxisme dan Teori Lainnya. Bandung: Mizan, 1986

Perwaatmadja, Karnaen A. Membumikan Ekonomi di Indonesia. Jakarta: Usaha Kami Penerbit Buku Pilihan, 1996

Rifa’i, Moh. Tafsîr al-Qur’ân al-Karîm; Terjemah/Tafsîr Al-Qur’ân. Semarang: CV. Wicaksana, 1993

Uyun, Q. (2015). Zakat, Infaq, Shadaqah, dan Wakaf Sebagai Konfigurasi Filantropi Islam. Islamuna: Jurnal Studi Islam, 2(2)

World Bank. (2020). World Bank Group and COVID-19 (coronavirus). https://www.worldbank.org/en/who-we-are/news/coronavirus-covid19. Diakses pada tanggal 14 Agustus 2020.

Yuliana, R. R. R. D. (2019). Sinergi Lembaga Teknologi Finansial dan Koperasi Dalam Pemanfaatan Teknologi Finansial Oleh Usaha Mikro, Kecil, dan Menengah di NTB. Jurnal Ekonomi dan Pembangunan, 27(1) 